\title{
Studying performance evaluation of hybrid e-bike using solar photovoltaic system
}

\author{
Safwan A. Hamoodi, Ahmed A. Abdullah Al-Karakchi, Ali N. Hamoodi \\ Technical College of Engineering/Mosul, Northern Technical University, Mosul, Iraq
}

\begin{tabular}{|c|c|}
\hline Article Info & ABSTRACT \\
\hline Article history: & Hybrid e-bike system is a bicycle included electric hub motor used to aid \\
\hline Received Aug 21, 2021 & $\begin{array}{l}\text { propulsion. A solar package with main components is built with it. This } \\
\text { study included the travelled distance divided by time under only the batteries }\end{array}$ \\
\hline Revised Oct 21, 2021 & and batteries with photovoltaic (PV) modules (at different hours during the \\
\hline Accepted Jan 13, 2022 & $\begin{array}{l}\text { day). A comparison between two methods is made and documented in this } \\
\text { paper. The paper aims to captivate the fettle and experiences with the use of }\end{array}$ \\
\hline Keywords: & $\begin{array}{l}\text { e-bike. Commuting distance per hour was approximately } 6.8 \mathrm{~km} / \mathrm{h} \text {. The } \\
\text { current limitations must not exceed }(10.4 \mathrm{~A}) \text { and the big challenge, no }\end{array}$ \\
\hline $\begin{array}{l}\text { DC motor } \\
\text { E-bike }\end{array}$ & $\begin{array}{l}\text { shading plops on solar panels due to rider. Finally, depending on the solar } \\
\text { irradiance with time curve, hybrid e-bike gave longer travelled distance with } \\
\text { respect to time as compared with the batteries case study. }\end{array}$ \\
\hline
\end{tabular}

This is an open access article under the CC BY-SA license.

Lead acid battery

Solar PV module

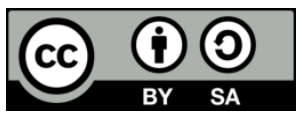

\section{Corresponding Author:}

Ahmed A. Abdullah Al-Karakchi

Technical College of Engineering/Mosul, Northern Technical University

Almajmo'aa althakafiea, Mosul, Iraq

Email: ahmedalkarakchi@ntu.edu.iq

\section{INTRODUCTION}

The motivation reason to design solar e-bike is to surmount the quandary with pollution and the economy. E-bike is the best solve for the technical application in the word [1]. E-bike is a battery functioned cart that is low fending cost, less pollution and very economical. It is very attractive and alternative to both traditional automobiles and conventional e-bike which providing a fun, efficient, environmentally and convenient manner to travel [2]. Battery bank is coupled with the electric DC motor in the e-bike structure. Now days this cart is manufactured at a very large scale and the power is stocked in a rechargeable battery bank which drives the DC motor [3].

Solar e-bike is sophisticated to study the pollution caused by e-bike. For remote and rural areas where fuels are not plenteous to drive two wheelers so that it can run under solar energy in addition to the low driving cost [4]. Solar energy is used to drive the motor and it is a free of cost. It different from others carts. Solar panel will be charged the battery bank while e-bike is running [5]. When the energy is not availed a pedal operation is used. In present scenario, the petroleum products are reaching to the peak under mark-up number of automobiles [6]. These oil products are hazard of exhaustion and non-renewable sources. Over the past few years, the prices of crude oil have significantly high value without turning back [7]. The form hybrid infers to more than one energy supply which is used to power part or all carts motive [8]. Solar energy may be also used to sell power for controls, communications and other auxiliary functions, DC motor is used in this work. Hybrid e-bike is a project that can carry both cleaner technology as well as a lesser reliance on oil [9]. 


\section{METHOD}

The requires research method included the components, hardware description, solar irradiance curve and flowchart algorithm.

\subsection{Components required}

Figure 1 depicts a solar hybrid e-bike that consist of $24 \mathrm{~V}$. Table 1 represents types of companents used in the project. Solar panels, DC motor, and sealed lead acid battery was used to build up the e-bike.

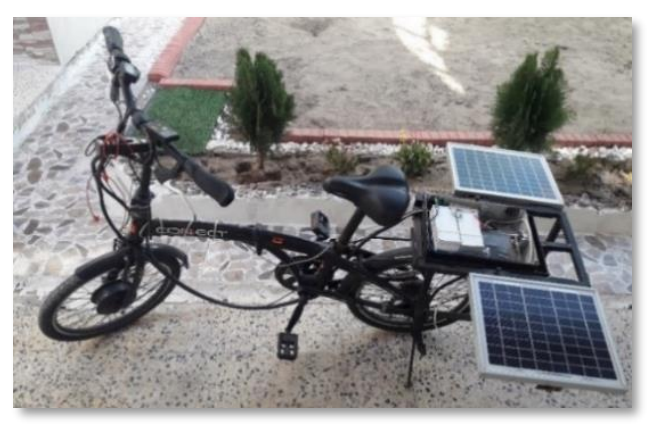

Figure 1. Solar hybrid e-bike

Table 1. Components of hybrid e-bike

\begin{tabular}{cc}
\hline No. & Components \\
\hline 1 & Solar panels \\
2 & DC motor \\
3 & Sealed lead acid battery \\
4 & Speedometer \\
5 & Manual control \\
\hline
\end{tabular}

\subsection{Hardware description}

The hardware components that have been used in this project are:

\subsubsection{Solar modules}

The e-bike appears to be powered by solar energy. Sunlight is converted to electricity by photovoltaic (PV) modules utilization PV effect [10]. There are two types of effects that solar modules can produce, one is PV and the other is photoelectric [11]. When using photoelectric effect, as soon as a metal is exposed to photons, it releases electrons that move to the conduction and valence bands, creating potential differences between the electrodes [12]. The solar e-bike is run by solar energy. With the assistance of a PV cell, the lead acid batteries are charged using solar energy [13]. Solar cells convert the sun light directly into electricity by using PV effect. Electromagnetic radiation is converted into electrical energy by the PV effect, which is then used to produce electricity [14]. Solar cells are manufactured as a module and connected in series or parallels to permit sunlight to pass and protecting the silicon's layers from the weather [15]. It is possible to obtain the desired voltage by connecting two small PV modules in series. Figure 2 represents solar modules. Table 2 illustrates the parameters of solar module.

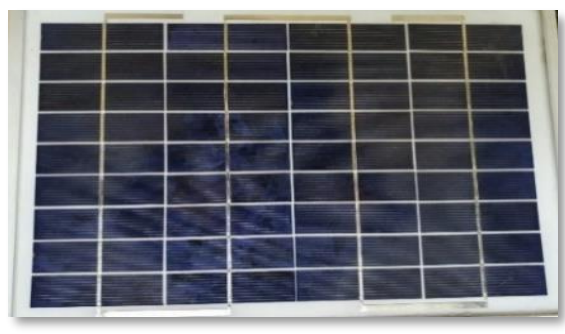

Figure 2. Solar module
Table 2. Parameter solar panel

\begin{tabular}{cc}
\hline Parameter & Value \\
\hline Max. voltage (V) & 18.9 \\
Max. current (A) & 0.53 \\
Max. power (W) & 10 \\
Short-circuit & 0.56 \\
current (A) & \\
Open-circuit & 22.4 \\
voltage (V) & \\
Normal operating & -40 to 85 \\
cell temp. $\left({ }^{\circ} \mathrm{C}\right)$ & \\
Dimention $(\mathrm{mm})$ & 360.300 .28 \\
\hline
\end{tabular}




\subsubsection{Hub DC motor}

A syllogistic DC motor has no brushes, which reduces the cost, fending, time, and efficiency of the motor. It is divided into two sections [16]. The fixed coils are represented on the inside, while the rotating magnet is represented on the outside. Many types of tiny magnetic field sensors set in the coils [17]. These sensors sense the position and direction of motor and called hall effect sensors. An extra electronic circuit must be added when using this type of motor. Figure 3 represents DC motor of the e-bike [18]. DC motor specifications are listed in Table 3.
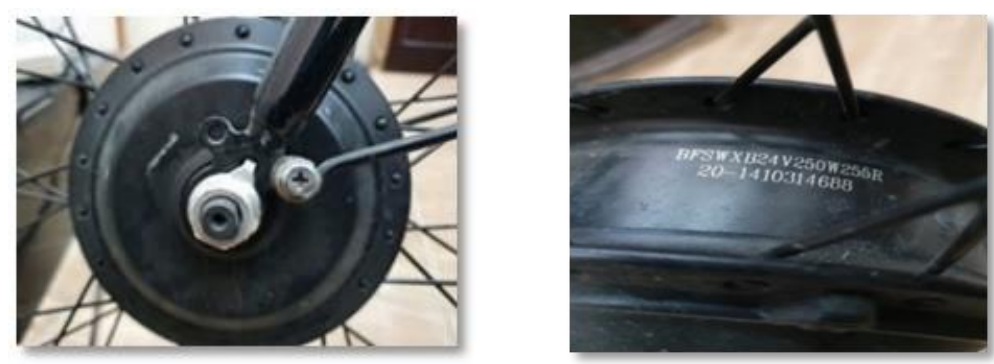

Figure 3. DC motor of e-bike

\subsubsection{Sealed lead acid battery}

The battery is one of the most important components in the design and implementation of a solar vehicle [19]. The battery must be able to charge from the solar module in order to power and push the e-bike. The most crucial factor to consider is whether or not this battery is compatible with an e-bike [20]. The final decision falls to choose the best battery type that compatible with the e-bike. Figure 4 represents the battery type. Battery specifications are listed in Table 4.

Table 3. DC motor specifications

\begin{tabular}{cc}
\hline Value & Parameter \\
\hline BFSWXB & Type \\
250 & Rated power (W) \\
$12-24$ & Rated voltage (V) \\
\hline
\end{tabular}

$\underline{\text { Table 4. Battery specifications }}$

\begin{tabular}{cc}
\hline Value & Parameter \\
\hline BFSWXB & Type \\
250 & Rated power $(\mathrm{W})$ \\
$12-24$ & Rated voltage $(\mathrm{V})$ \\
\hline
\end{tabular}

\subsubsection{Speedometer}

The speed/distance sensor is installed on the front fork of the e-bike with the same side of the magnet, and the sensor is secured on the front fork using the tie of connection [21]. Adjust the magnet and sensor's relative positions, then plane them together and make the spacing between them $1 \mathrm{~mm}[22]$. Don't install the sensor in the magnet's center. Speedometer was fixed on the right side of handle bar as shown in Figure 5.

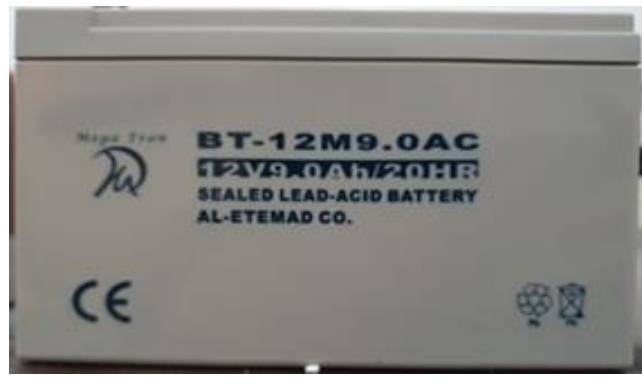

Figure 4. Battery type

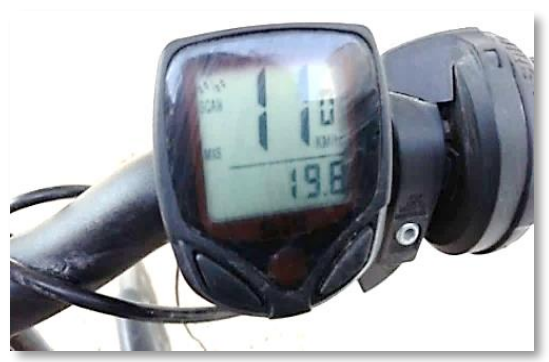

Figure 5. Speedometer

where: Speed $=\frac{\text { distance }}{\text { time }}$

Wheel circumference $=$ circumference of a circle $=2 \times$ radius $\times \mathrm{Pi}$

No. of cycle=distance/circumference 


\subsubsection{Revoshift}

Set refers to a manner of controlling the speed of a motor and on the right side of the handle bar, so that it connected in the e-bike to decrease or increase the speed based on the situation [23]. Figure 6 illustrates the throttle (Revoshift).

\subsubsection{Motor controller}

An electronic motor controller is used to provide a fixed voltage for brushless DC motors (BLDCs) [24]. It consists of various types of which reinstructs to excite the mainly coils in order to rotate the rotor, this controller included a microprocessor, transistors, MOSFETs, and other components that provide overcurrent, under voltage, and overvoltage protection for the motor [25]. Figure 7 represents the electric motor controller, and its specifications (throttle parameters) are listed in the Table 5.

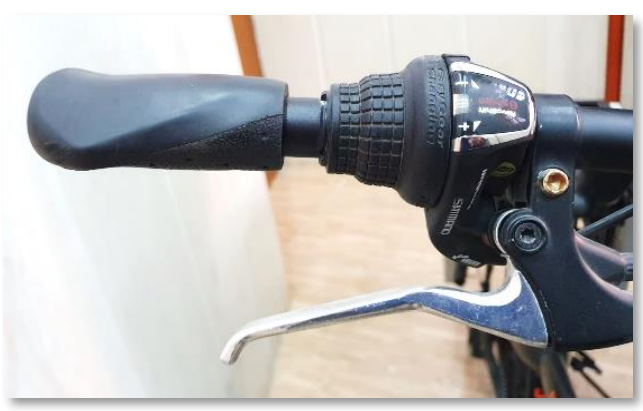

Figure 6. Throttle e-bike

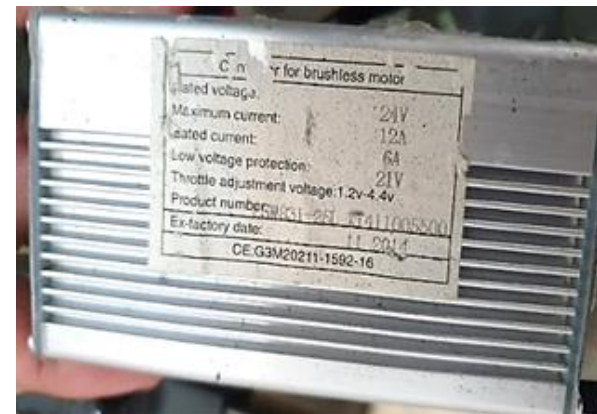

Figure 7. Electric motor controller

Table 5. Throttle parameters

\begin{tabular}{cl}
\hline Parameter & \multicolumn{1}{c}{ Value } \\
\hline 24 & Rated voltage (V) \\
12 & Max. current (A) \\
6 & Rated current (A) \\
21 & Low voltage protection (V) \\
$1.2-4.4$ & Throttle adjustment voltage (V) \\
L5W831-261,X1411005500 & Product No. \\
\hline
\end{tabular}

\subsubsection{Power mode}

On the e-bike, there are more than one levels of electric assist available. Three power mode levels available in this e-bike [26]. In this work, the highest level (H-mode) is chosen in order to obtain actual results in less time [27]. Figure 8 shows the power mode's shape.

\subsubsection{Blocking diode}

Figure 9 depicts the shape of a blocking diode used to prevent reverse current after sunset and ensure that no discharge from the batteries occurs (no batteries charging losses) [28], [29].

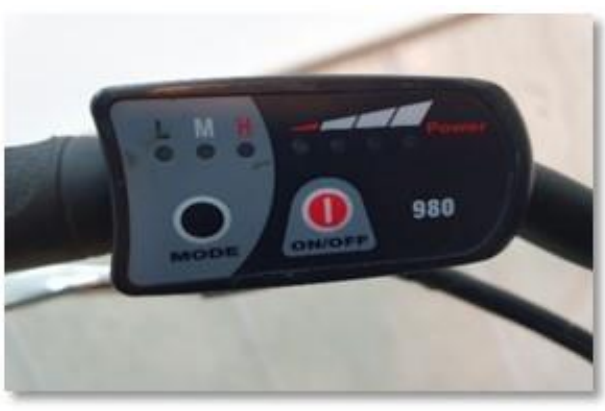

Figure 8. Power mode

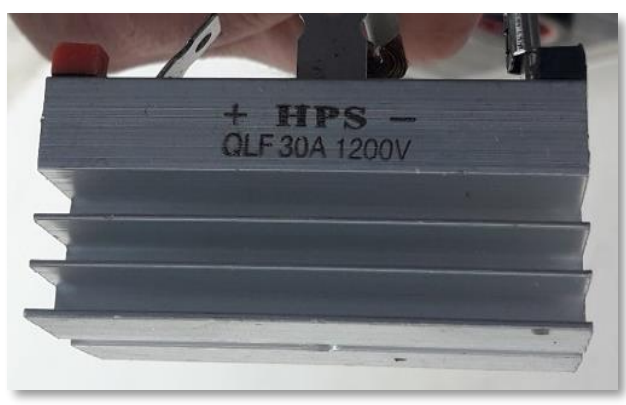

Figure 9. Blocking diode 


\section{SOLAR IRRADIANCE AND FLOWCHART OF HYBRID E-BIKE}

The distribution of solar irradiance with time during July month is illustrated in Figure 10 [30]. International measurements of solar irradiance are taken on a horizontal surface, and the highest value of beam irradiance was indicated in July on a horizontal surface.

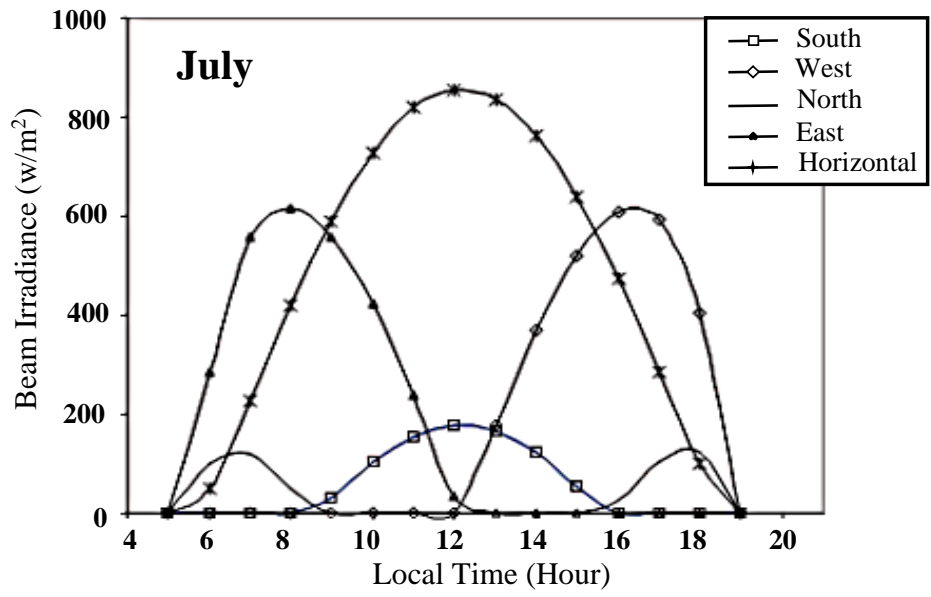

Figure 10. Solar irradiance vs time during July

Hybrid system includes two different ways for charging the batteries bank: wall charger and solar PV charger as shown in Figure 11. This flowchart illustrates the charging process according to both directions. If the battery bank is fully charged, the controller will send a signal to the motor hub, causing the E-bike to move via throttle commands.

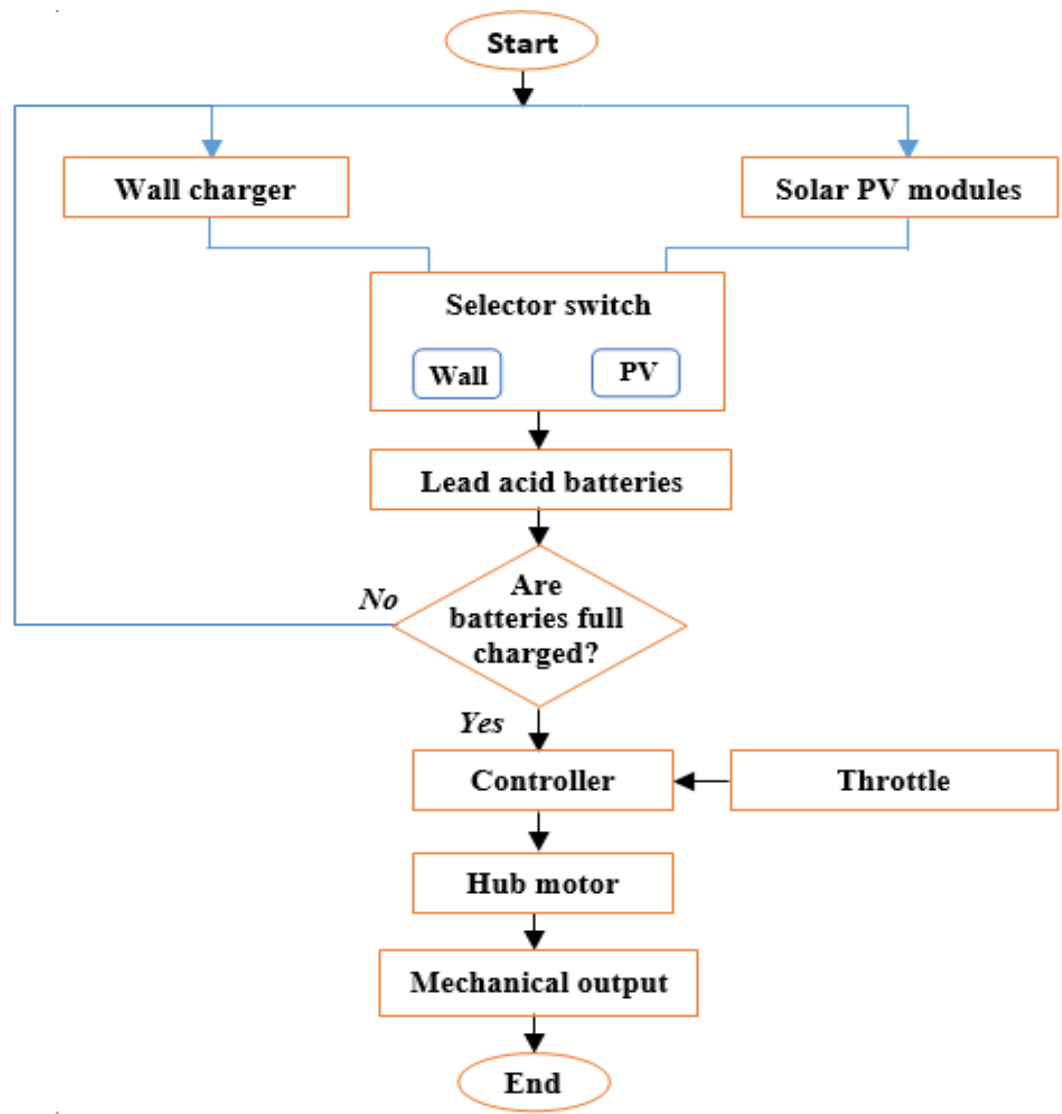

Figure 11. Flowchart of hybrid e-bike 


\section{RESULTS AND DISCUSSION}

\subsection{Without solar modules (with batteries)}

The $(\mathrm{km} / \mathrm{h})$ difference between two readings of speedometer on e-bike by using only batteries was illustrated in Figure 12(a) before setting off and in Figure 12(b) after setting off, the result shown in Table 6.

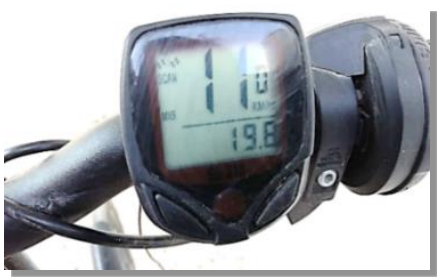

(a)

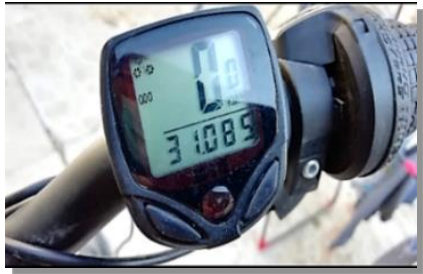

(b)

Figure 12. Speedometer $(\mathrm{km} / \mathrm{h})$ with only batteries (a) before setting off and (b) after setting off

Table $6 . \mathrm{Km} / \mathrm{h}$ readings with only batteries

\begin{tabular}{ccc}
\hline Traveled distance per hour $(\mathrm{km} / \mathrm{h})$ & After setting off $(\mathrm{km} / \mathrm{h})$ & Before setting off $(\mathrm{km} / \mathrm{h})$ \\
\hline 11.285 & 31.089 & 19.8 \\
\hline
\end{tabular}

\subsection{Under solar modules}

The $(\mathrm{km} / \mathrm{h})$ difference between two readings of speedometer on e-bike under solar from the hour (11-12) a.m., (12-1) p.m and (1-2) p.m., (3-4) p.m., (4-5) p.m. and (5-6) p.m were illustrated in Figures 13(a) to 13(1). From Figure 13 the readings of $\mathrm{km} / \mathrm{h}$ under solar radiation for all time periods can be listed in Table 7.

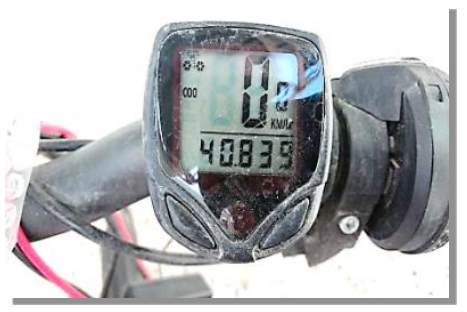

(a)

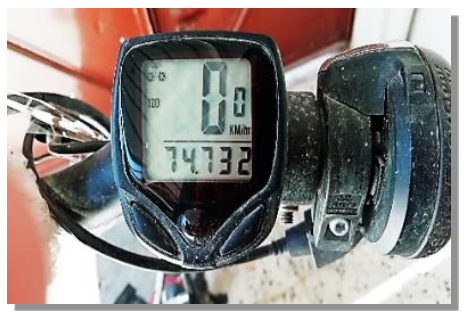

(d)

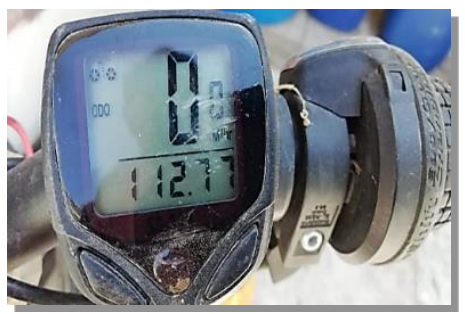

(g)

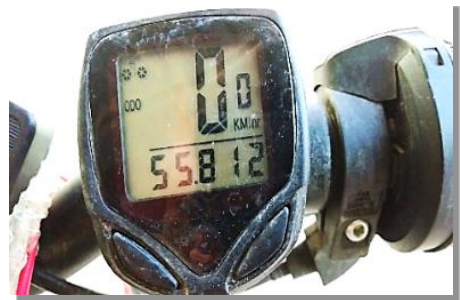

(b)

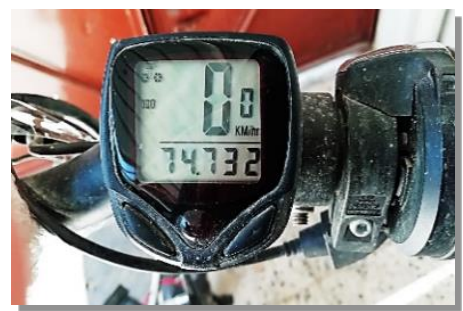

(e)

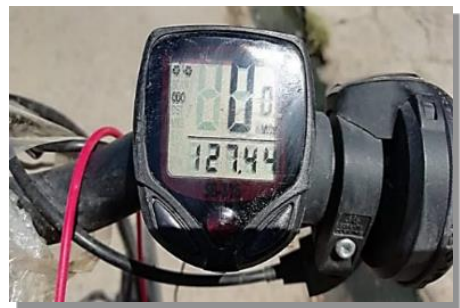

(h)

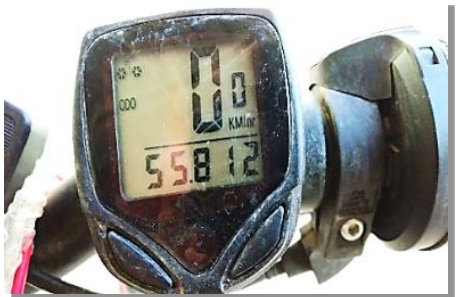

(c)

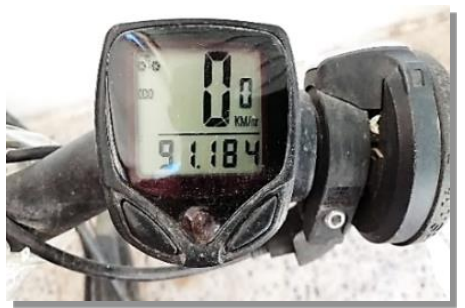

(f)

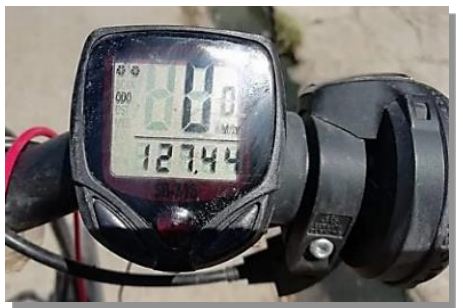

(i)

Figure 13. Speedometer (km/h) under solar from the hour (11-12) a.m., (12-1) p.m., (1-2) p.m., (3-4) p.m., 
(4-5) p.m. and (5-6) p.m. (a, c, e, g, I, k) before setting off (b, d, f, h, j, l) after setting off

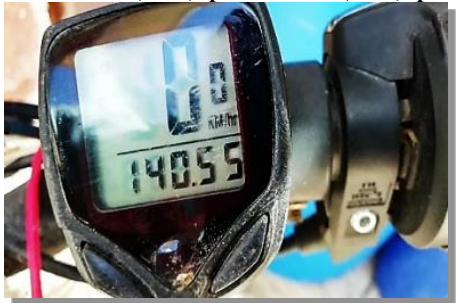

(j)

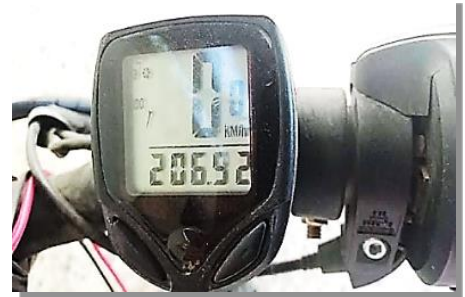

(k)

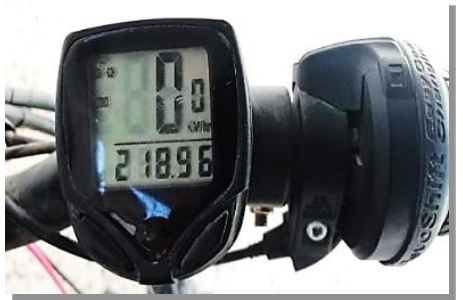

(1)

Figure 13. Speedometer (km/h) under solar from the hour (11-12) a.m., (12-1) p.m., (1-2) p.m., (3-4) p.m., (4-5) p.m. and (5-6) p.m. (a, c, e, g, I, k) before setting off (b, d, f, h, j, l) after setting off (continue)

Table $7 . \mathrm{Km} / \mathrm{h}$ readings under solar radiation

\begin{tabular}{cccc}
\hline Time & Before setting off $(\mathrm{km} / \mathrm{h})$ & After setting off $(\mathrm{km} / \mathrm{h})$ & Traveled distance per hour $(\mathrm{km} / \mathrm{h})$ \\
\hline$(11-12)$ & 40.839 & 55.812 & 14.973 \\
$(12-1)$ & 55.812 & 74.732 & 18.92 \\
$(1-2)$ & 74.732 & 91.184 & 16.45 \\
$(3-4)$ & 112.17 & 127.44 & 14.67 \\
$(4-5)$ & 127.44 & 140.55 & 13.11 \\
$(5-6)$ & 206.52 & 218.96 & 12.04 \\
\hline
\end{tabular}

The relationship between the difference values $(\mathrm{km})$ for each period and the time is expressed as the histogram shown in Figure 14, based on the above results that were measured under sunlight.

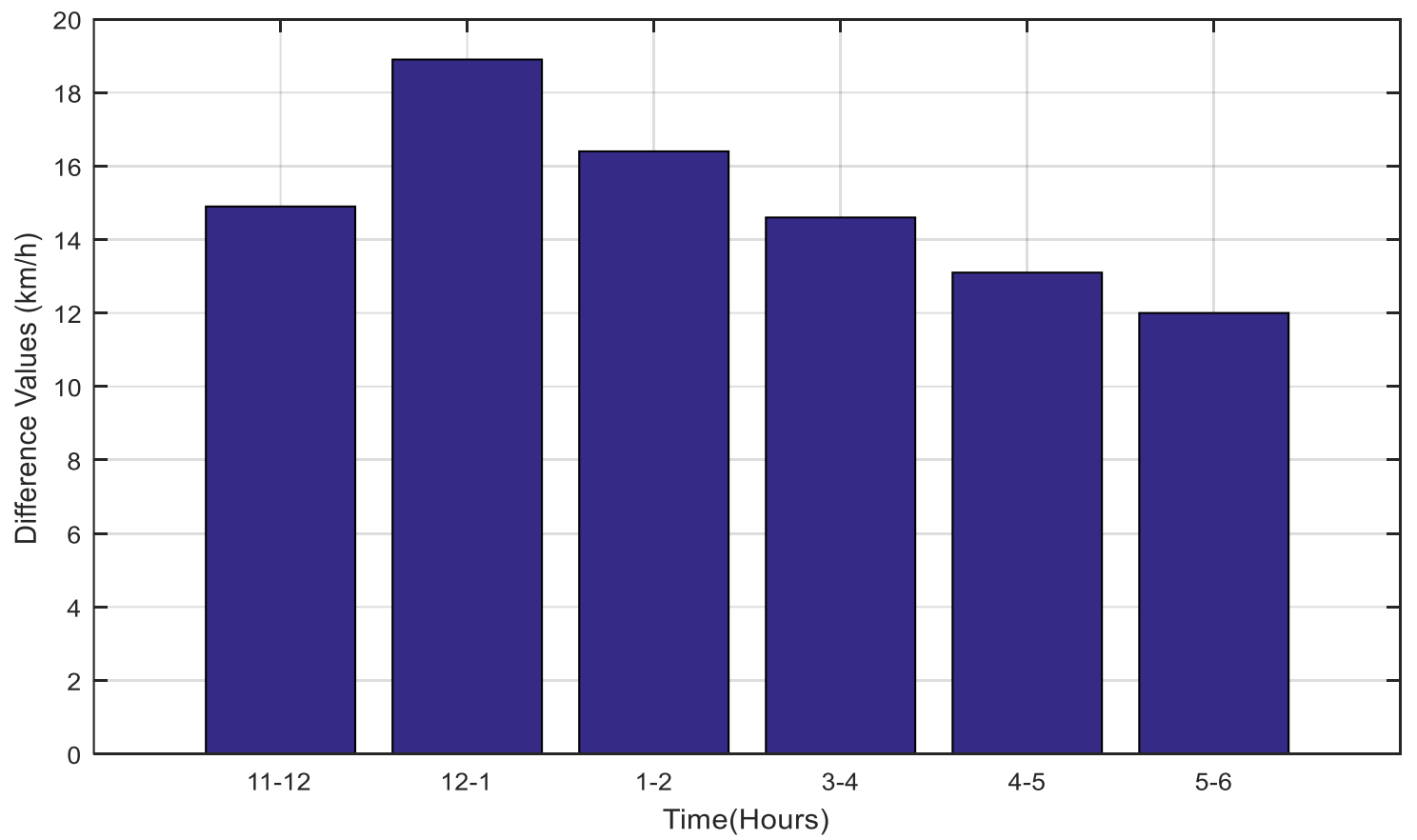

Figure 14. Histogram for difference speedometer values $(\mathrm{km} / \mathrm{h})$ of each period with respect to time

\section{CONCLUSION}

Hybrid e-bike solves many environmental issues and are considered a pollution-free mode of transportation and lessens reliance on fossil fuels. The least value in speed under solar gives an increase equal to $(0.755 \mathrm{~km} / \mathrm{h})$ as compared with the battery only, the highest traveled distance divided by time is investigated at (12:00-1:00) p.m and the highest difference in speed under solar is $(6.88 \mathrm{~km} / \mathrm{h})$. The difference value in speed between peak value under solar and the value under only batteries is $(7.635 \mathrm{~km} / \mathrm{h})$ 
and the maximum traveled distance divided by time value is obtained at 12:00-1:00 p.m. but the minimum value is obtained at batteries only, therefore the hybrid system based solar and batteries gives the highest travelling distance. This project comprises from two parts, software and hardware. The software part included controller program and the hardware part included hybrid e-bike with its components. The specifics about the project are using solar energy to recharge the batteries and using strong torque motor to drive the hybrid e-bike.

\section{REFERENCES}

[1] R. Anjana, S. Sharmila, A. Aswin, M. V. Kumar, and K. R. Kumar, "Design and Implementation of Solar Bicycle," International Research Journal of Engineering and Technology, vol. 6, no. 3, pp. 2197-2202, Mar 2019.

[2] Sh. Nagwe, T. Shaikh, Sangale, J. Sapkale and A. Singh, "Solar E-bike," International Journal of Advance Research and Innovative Ideas in Education, vol. 5, no. 1, pp. 590-596, 2019.

[3] P. Hazarathaiah, Y. Ashok, P. Vijaya and M. Sreenivasulu, "Design and Fabrication of Hybrid Electric Bike," International Journal of Applied Engineering Research, vol. 14, no. 4, pp. 930-935, 2019.

[4] M. B. Chouhary, S. Talpur, T. Zafar, M. Hussain, A. Raza, and H. H. Zuberi, "Solar Powered Electric Bike," European International Journal of Science and Technology, vol. 5, no. 1, pp. 77-82, Jan. 2016.

[5] K. S. Mishra, Sh. V. Gadhawe, D. C. Chaudhari, B. Varma and S. B. Barve, "Design and Development of Solar Hybrid E-bike," International Journal of Current Engineering and Technology, Special Issue 4, pp. 377-381, Mar., doi: 10.14741/Ijcet/22774106/spl.4.2016.76. 2016.

[6] S. A. Hakeem, K. N. Rajesh and M. Sudhakaran, "Solar E- Bicycle Using Hub Motor," International research journal in advanced engineering and technology, vol. 5, no. 2, pp. 4277-4280, 2019.

[7] A. V. Shivashimpi, B. S. Ambalgi, M. J. Zambare, S. A. Umare and P. S Phutane, "Performance Analysis of Solar Powered E-Ebike," International Journal of Advanced Research in Electrical, Electronics and Instrumentation Engineering. vol. 8, no. 10, Oct. 2019.

[8] G. S. Aikenhead, "Bicycle Applications for On-Board Solar Power Generation System Adaptation," Guelph Engineering Journal, vol. 4, pp. 9-23, 2011.

[9] T. Markel, K. Bennion and W. Kramer, J. Bryan and J. Giedd, "Field Testing Plug-in Hybrid Electric Vehicles with Charge Control Technology in the Xcel Energy Territory." U.S. Department of Energy, rep. NREL/TP-550-46345, Aug. 2009.

[10] A. Muetze and Y. C. Tan, "Electric bicycles - A performance evaluation," in IEEE Industry Applications Magazine, vol. 13, no. 4, pp. 12-21, July-Aug. 2007, doi: 10.1109/MIA.2007.4283505.

[11] C. E. Thomas, "Fuel cell and battery electric vehicles compared," International Journal of Hydrogen Energy, vol. 34, no. 15, pp. 6005-6020, August 2009, doi: 10.1016/j.ijhydene.2009.06.003.

[12] S. Matey, D. R. Prajapati, K. Shinde, A. Mhaske, and A. Prabhu, "Design and Fabrication of Electric Bike," International Journal of Mechanical Engineering and Technology, vol. 8, no. 3, pp. 245-253, Mar. 2017.

[13] H. M. Saber and D. Lal, "Assessment of Solar Energy Distribution for Installing Solar Panels Using Remote Sensing \& GIS Techniques," International Journal of Advanced Research in Engineering and Technology, vol. 5, no.10, pp. 157-164. Oct. 2014.

[14] S. Manish, J. K. Rajak, V. K. Tiwari and Rakesh, "Quad Bike Design and Simulation: A Pre-Manufacturing Methodology," International Journal of Advanced Research in Engineering and Technology, vol 5, no. 6, pp. 68- 76, Jun. 2014.

[15] A. A. A. Al-Karakchi, F. E. Nashad, G. Putrus, S. Foti, D. Smith and M. Elsdon, "Cost-effective Integration System of Solar Cell Powered Remote Small-Size Wireless Communication," 2019 2nd International Conference on Electrical, Communication, Computer, Power and Control Engineering (ICECCPCE), 2019, pp. 19-22, doi: 10.1109/ICECCPCE46549.2019.203741.

[16] G. S. Aikenhead, "Bicycle Applications for On-Board Solar PowerGeneration System Adaptation," Guelph Engineering Journal, vol. 4, pp. 9-23. 2011.

[17] G. R. Mouli et al., "Solar Powered E-Bike Charging Station with AC, DC and Contactless Charging," 2018 20th European Conference on Power Electronics and Applications (EPE'18 ECCE Europe), 2018, pp. P.1-P.10.

[18] C. Chen and M. Cheng, "Implementation of a Highly Reliable Hybrid Electric Scooter Drive," in IEEE Transactions on Industrial Electronics, vol. 54, no. 5, pp. 2462-2473, Oct. 2007, doi: 10.1109/TIE.2007.900357.

[19] R. A. Mohammed, S. A. Hamoodi, and A. N. Hamoodi, "Comparison Between Two Calculation Methods for Designing A StandAlone PV System According to Mosul City Basemap,” De Gruyter,vol. 11, no. 1, pp. 782-789. Des. 2021, doi: 10.1515/eng2021-0075.

[20] D. Iannuzzi, L. Rubino, L. P. Di Noia, G. Rubino, and P. Marino, "Resonant Inductive Power Transfer for an E-BikeCharging Station," Electric Power Systems Research, vol. 140, pp. 631-642, 2016, doi: 10.1016/j.epsr.2016.05.010.

[21] F. Pellitteri, G. Ala, M. Caruso, S. Ganci and R. Miceli, "Physiological compatibility of wireless chargers for electric bicycles," 2015 International Conference on Renewable Energy Research and Applications (ICRERA), 2015, pp. 1354-1359, doi: 10.1109/ICRERA.2015.7418629.

[22] S. A. Hamoodi, A. N. Hamoodi, and G. M. Haydar, "Automated Irrigation System Based On Soil Moisture Using Arduino Board,” Bulletin of Electrical Engineering and Informatics, vol. 9, no. 3, pp. 870-876. June 2020, doi: 10.11591/eei. v9i3.1736.

[23] K. J. Astrom, R. E. Klein and A. Lennartsson, "Bicycle dynamics and control: adapted bicycles for education and research," in IEEE Control Systems Magazine, vol. 25, no. 4, pp. 26-47, Aug. 2005, doi: 10.1109/MCS.2005.1499389.

[24] M. M. Trivedi, M. K. Budhvani, K. M. Sapovadiya, D. H. Pansuriya and C. D. Ajudiya, "Design and Development of E-Bike-A Review," Iconic Research and Engineering journals, vol. 1, no. 5, pp. 36-43, Nov. 2017.

[25] V. Vega-Garita, L. Ramirez-Elizondo, G. R. C. Mouli and P. Bauer, "Review of residential PV-storage architectures," 2016 IEEE International Energy Conference (ENERGYCON), 2016, pp. 1-6, doi: 10.1109/ENERGYCON.2016.7514039.

[26] S. A. Hamoodi, F. I. Hameed, and A. N. Hamoodi, "Pitch Angle Control of Wind Turbine Using Adaptive Fuzzy-PID Controller," EAI Endorsed Transactions on Energy Web, vol. 7, no. 28, pp. 1-8, 2020, doi: 10.4108/eai.13-7-2018.165500

[27] A. Q. Jakhrani, A. K. Othman, A. R. H. Rigitand and S. R. Samo, "Comparison of Solar Photovoltaic Module Temperature Models," World Appl. Sci. J., vol. 14, pp. 1-8. 2011.

[28] A. N. Hamoodi, S. A. Hamoodi and R. A. Mohammed, "Photovoltaic Modeling and Effecting of Temperature and Irradiation on I-V and P-V Characteristics," International Journal of Applied Engineering Research, vol. 13, no. 5, pp. 3123-3127, 2018. 
[29] A. N. Hamoodi, S. A. Hamoodi and A. G. Abdulla, "Photovoltaic-Battery System Tested under Sun Irradiance," London Journal Engineering Research, vol. 18, no. 2. Pp. 65-75. 2018.

[30] K. D. Poore, J. Wang and W. B. Rossow, "Cloud Layer Thicknesses from a Combination of Surface and Upper-Air Observations," J. Climate, vol. 8, no. 3, pp. 550-568, 1995, doi: 10.1175/1520-0442.

\section{BIOGRAPHIES OF AUTHORS}
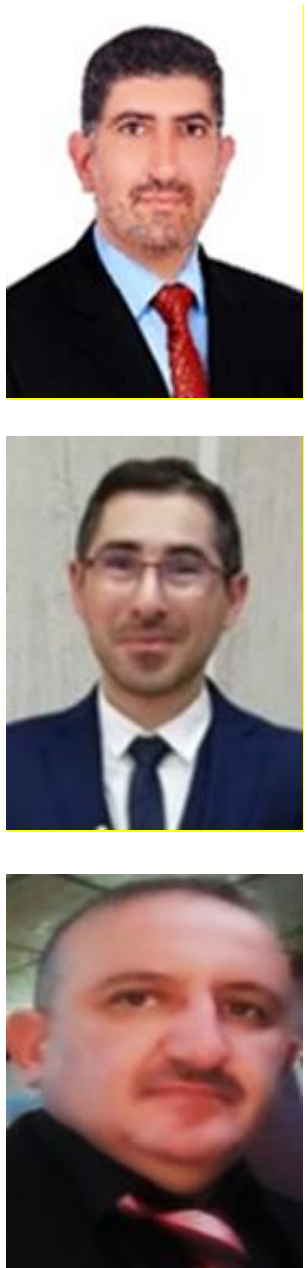

Safwan Assaf Hamoodi (D) Sd SC P obtained his B.Sc. in 2001, M.SC 2008 in Electrical Power Engineering from Northern Technical University. He had a titular as lecturer in 2019. $\mathrm{He}$ is working in the Electrical Engineering Specializing in Electrical Power Techniques Engineering Department at Northern Technical University (NTU), Technical College of Engineering, Mosul-Iraq. He can be contacted at email: safwan79azb@ntu.edu.iq.

Ahmed A. Abdullah Al-Karakchi (iD 8d SC P obtained his B.Sc. in 2001 from AlMustansiriyah University, M.SC in 2004 from University of Technology, and Ph.D. in (2018) from Northumbria University, UK. Currently. He had a titular as lecturer from 2019. He is working in the Electrical Engineering Specializing in Electrical Power Techniques Engineering Department at Northern Technical University (NTU), Technical College of Engineering/Mosul-Iraq. He can be contacted at email: ahmedalkarakchi@ntu.edu.iq.

Ali N. Hamoodi (iD SC P obtained his B.Sc. in 1996, M.SC in 2000 from Mosul University, and Ph.D. in 2011 from the University of Aleppo, Syria, currently. He had a titular Assis. Prof. in 2019. He is working in the Electrical Engineering Specializing in Electrical Power Techniques Engineering Department at Northern Technical University (NTU) Technical College of Engineering/Mosul-Iraq. He can be contacted at email: ali_n_hamoodi74@ntu.edu.iq. 